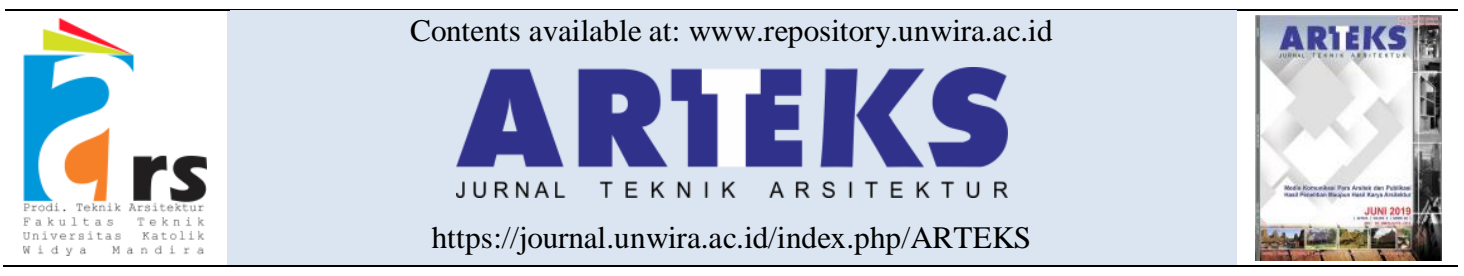

Research paper

doi: $10.30822 /$ arteks.v5i2.442

\title{
Konsep arsitektur biomimetik pada bangunan Oseanarium
}

\section{Adhelia Adjani Rahmah, Wafirul Aqli*}

Jurusan Arsitektur, Fakultas Teknik, Universitas Muhammadiyah Jakarta Jl. Cempaka Putih Tengah 27, Jakarta -10510, Indonesia

\begin{tabular}{|c|c|}
\hline & \\
\hline ARTICLE INFO & ABSTRACT \\
\hline \multirow[b]{2}{*}{$\begin{array}{l}\text { Article history: } \\
\text { Received March 22, } 2020 \\
\text { Received in revised form April 01, } 2020 \\
\text { Accepted May 11, } 2020 \\
\text { Available online August } 01,2020\end{array}$} & The concept of biomimetic in the Oceanarium building \\
\hline & $\begin{array}{l}\text { The concept of biomimetic architecture, which is rarely heard, has } \\
\text { many advantages that can be applied to architectural work. The } \\
\text { purpose of using the concept of biomimetic architecture is to } \\
\text { maximize functions, achieve energy efficiency, and improve the }\end{array}$ \\
\hline $\begin{array}{l}\text { Keywords: } \\
\text { Concept architecture } \\
\text { Concept biomimetic } \\
\text { Oceanarium building }\end{array}$ & $\begin{array}{l}\text { quality of objects and user activities by applying one or more } \\
\text { biological criteria from } 11 \text { biological criteria. The oceanarium } \\
\text { building is a museum building with marine life as an object of the } \\
\text { exhibition with functions as educational facilities, recreation } \\
\text { facilities, observation centers, and marine life conservation } \\
\text { facilities. The oceanarium building is one of the educational } \\
\text { facilities that are most readily accepted by the public. This has } \\
\text { become very important at this time where the need for education } \\
\text { about biota and marine life is increasinglythreatened by landfill and }\end{array}$ \\
\hline $\begin{array}{l}\text { Jurusan Arsitektur, Fakultas } \\
\text { Universitas Meknik, } \\
\text { Indonesia }\end{array}$ & $\begin{array}{l}\text { the uncontrolled fishing on a large scale. Research on architectural } \\
\text { concepts in oceanarium buildings uses qualitative research } \\
\text { methods. By collecting data and studies both from observation and } \\
\text { literature. The conclusion in the form of the influence of the existence } \\
\text { of each biological criterion applied to an oceanarium building. }\end{array}$ \\
\hline
\end{tabular}

\section{Pendahuluan}

Tingkat kekayaan dan potensi laut Indonesia sudah sangat tersohor, namun hal ini tidak dilandaskan atas kesadaran masyarakat Indonesia (Hijriati and Mardiana 2014). Masyarakat Indonesia membutuhkan edukasi lebih mengenai laut dan kehidupan didalamnya. Bangunan oseanarium merupakan salah satu langkah efektif yang dapat memberikan edukasi dan menimbulkan rasa cinta masyarakat Indonesia terhadap laut Indonesia yang sangat kaya akan biodiversitasnya (Sunarmi 2014).

Bangunan oseanarium yang diharapkan menjadi sarana edukasi, rekreasi, observasi dan konservasi membutuhkan konsep rancangan yang kuat dan terintegritas dengan alam. Tujuan bangunan oseanarium yang ingin memulihkan keadaan laut diharuskan seminimalis mungkin menghasilkan dampak negatif bagi alam di sekitarnya. Sehingga, sejalan dengan tujuan konsep arsitektur biomimetik. Adanya peningkatan pengakuan bahwa cara edukasi informal seperti kebun binatang dan akuarium memiliki peluang untuk berkontribusi besar pada program edukasi individu (Kelly et al. 2014).

Selain itu, bangunan oseanarium mampu menjadi sebuah lembaga konservasi bagi biota laut itu sendiri. Dimana semua biota dirawat dengan keperluan dari tiap spesifik biota untuk dilepaskan kembali ke alam (Larasati, Purnomo, and Hardiyati 2018). Arti dari kata konservasi itu sendiri yang berasal dari kata conservation yang disusun dari beberapa suku kata yakni con (together) dan servare (keep/save) secara bijaksana (wise use). Hal ini diartikan pada masa sekarang sebagai the wise use of nature resource 
(pemanfaatan sumber daya alam secara bijaksana) (Purwantiasning 2015).

Permasalahan yang akan dijawab pada penelitian ini adalah pengaruh dari penerapan arsitektur biomimetik pada bangunan oseanarium. Bagaimana bentuk penerapan dari arsitektur biomimetik pada bangunan oseanarium?

Penelitian ini didasari oleh teori dasar mengenai arsitektur biomimetik pada buku Biomimetics in Architecture (Architekturbionik) oleh Lebedev warga negara Rusia. Menurut Lebedev, terdapat sebelas kriteria biologis yang dapat diterapkan pada karya arsitektur dan dikerucutkan oleh peneliti menjadi sembilan. Sembilan kriteria biologis tersebut yaitu: Keterbukaan (oppenness), organisasi diri (selforganisation), batasan (limitation), keteraturan (order), penyebaran (propagation), pertumbuhan (growth), energi (energy), reaksi (reaction), evolusi (evolution), dan mimesis (peniruan) (Knippers, Nickel, and Speck 2016).

Penelitian ini bertujuan untuk membuktikan bahwa penggunaan konsep arsitektur biomimetik layak untuk dikembangkan dan digiatkan penggunaannya. Meskipun sudah diterapkan di beberapa karya arsitektur, namun pembuatan konsep desain yang sukses masih penuh tantangan (Badarnah and Kadri 2015). Maka dengan mengembangkan prinsip arsitektur biomimetik menurut Lebedev, dilakukan penelitian terkait penerapannya terhadap bangunan yang lebih spesifik yaitu oseanarium dan pada lokasi spesifik yaitu Indonesia dengan iklim tropisnya.

\section{Metode penelitian}

Metode penelitian menggunakan metode deskriptif kualitatif guna menggambarkan dan mendeskripsikan tiap poin pembahasan secara jelas. Lokasi penelitian dilakukan pada dua studi kasus bangunan oseanarium. Studi kasus pertama yaitu Taman Akuarium Air Tawar, Taman Mini Indonesia Indah (TMII) Jakarta dan studi kasus kedua yaitu SeaWorld Ancol, Jakarta. Pada tiap studi kasus dilakukan pengambilan data dari observasi langsung dan beberapa arsip gambar arsitektural bangunan. data diolah dengan menganalisis keberadaan tiap 9 kriteria pada keseluruhan data bangunan. Berikut merupakan pemahaman dari tiap kriteria biologis: Keterbukaan (openness), merupakan sebuah kriteria yang dapat dilihat maupun dirasakan oleh pengguna bangunan, baik dari aspek aksibilitas, visibilitas dan metaforis; Organisasi diri (selforganisation), sebagai cara bangunan menyesuaikan diri terhadap kondisi lingkungan sekitarnya; Batasan (limitation), merupakan kriteria yang menggambarkan kapasitas dari sebuah ukuran pada bangunan terutama ruang; Keteraturan (order), penggunaan sebuah pola pada elemen arsitektural bangunan terutama pada struktur; Penyebaran (propagation), pengelompokan elemen arsitektural seperti ruang berdasarkan fungsinya; Pertumbuhan (growth), keberlanjutan fungsi bangunan dalam memenuhi kapasitas atau kegiatan di dalamnya; Energi (energy), kemampuan bangunan dalam memaksimalkan efisiensi energi seperti menggunakan sistem bangunan yang mampu menekan penggunaan sumber daya habis terpakai yang mampu menyeimbangkan sistem bangunan dengan alam sekitar (Amna 2017); Reaksi (reaction), hal yang ditemukan berubah paska huni dan dapat menjadi tolak ukur keberlanjutan dari fungsi ruang atau bangunan (Dewi Wulansari and Wihardyanto 2017); Evolusi (evolution), perubahan kasat mata yang terlihat jelas pada fasad bangunan yang dipengaruhi zaman; dan Mimesis (peniruan), penggunaan wujud atau cara kerja sebuah makhluk hidup atau alam pada bangunan, bangunan masa kini menerapkannya pada sistem struktur dan material (Schouten, Sangkertadi, and Siregar 2015).

\section{Temuan dan pembahasan}

Biomimetik disebut juga bionik di negara-negara Eropa (Suryadi 2018). Adapun beragam istilah yang memiliki hubungan dengan biomimetik seperti biomorfologi, biomekanik, dan banyak lagi (Eman and Rogi 2013). Biomimetik merupakan sebuah terminologi yang menggambarkan suatu hal yang dibuat manusia dengan menirukan sebuah sistem, cara kerja maupun desain dari alam (Eman and Rogi 2013). Tantangan besar dalam mengaplikasikan sebuah teknologi atau bahan bioinspired (terinspirasi dari alam) adalah disaat memahami prinsip-prinsip desain yang mendasari dan mekanisme fisik sebuah organisme (Aizenberg and Fratzl 2009). Ada beberapa prinsip alam yang dapat dipelajari seperti alam yang dapat menyesuaikan bentuk dan fungsi, dan banyak lagi (Hartono, Egam, and Sembel 2018). Dalam buku Architekturbionik, 
Lebedev menyebutkan sebuah sistem sudut pandang mengenai hubungan antara sistem kehidupan alam dan segenap kriteria biologis dengan penerjamahannya ke dalam sistem arsitektur (Gruber 2011). Adapun hal penting dalam bidang arsitektur yaitu membedakan antara biomimetik dan biomorphism. Biomimetik mengedepankan mimesis dalam fungsional bangunan, sedangkan biomorphism mengedepankan bentuk dari mimesis alam tersebut (Pawlyn 2019).

Analisis arsitektur biomimetik pada studi kasus Keterbukaan (openness)

Pada gambar 1, terlihat penggunaan struktur atap bangunan taman akuarium air tawar. Struktur atap cangkang dengan material atap berupa kaca dapat diterjemahkan sebagai sifat keterbukaan pada bangunan. Atap dapat menghadirkan keberadaan langit dan mendukung ruang peragaan ekosistem sungai. Pengguna bangunan dapat merasakan kriteria keterbukaan di bawah atap dengan memberikan imajinasi akan ekosistem sungai yang nyata.

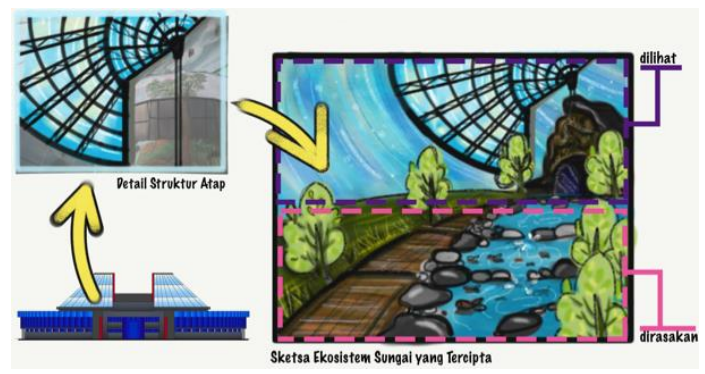

Gambar 1. Keterbukaan metaforis pada struktur atap Taman Akuarium Air Tawar

Kriteria keterbukaan dapat pula ditemukan dari aspek asksesibilitas bangunan. Pada gambar 2, denah bangunan SeaWorld Ancol dirancang hanya dengan membagi ruang berdasarkan fungsi utama yaitu admin dan eksebisi. Pengunjung dapat menjelajahi ruang eksebisi setelah mengakses zona ruang admin atau lobby dan kembali ke lobby setelah selesai menjelajah ruang eksebisi. Ruang eksebisi sebagian besar dirancang tanpa adanya pembatas antar zona objek yang dipamerkan. Hal ini membebaskan pengunjung dalam mengakses tiap objek eksebisi tanpa berpindah ruang. Sehingga, pengguna bangunan dapat bersikulasi bebas tanpa terarah di dalamnya.

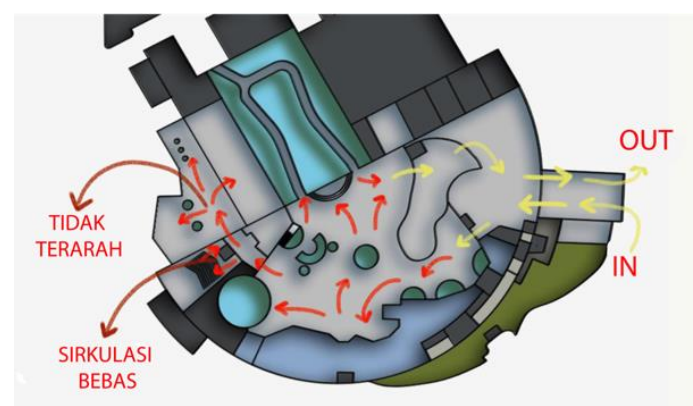

Gambar 2. Keterbukaan aksesibilitas pada SeaWorld Ancol

Organisasi diri (self-organisation)

Material kulit bangunan dapat dirancang responsif dan cerdas untuk mencapai kemampuan beradaptasi terhadap kondisi alam sekitar (AlObaidi et al. 2017). Kriteria organisasi diri yang dapat terlihat dari suatu elemen arsitektural yang berubah atau menyesuaikan diri dengan alam tidak didapati pada bangunan Taman Akuarium Air Tawar. Terlihat pada gambar 3, penggunaan struktur yang bersifat rigid dan material beton tidak memungkinkan adanya aktivitas penyesuaian diri terhadap kondisi alam.

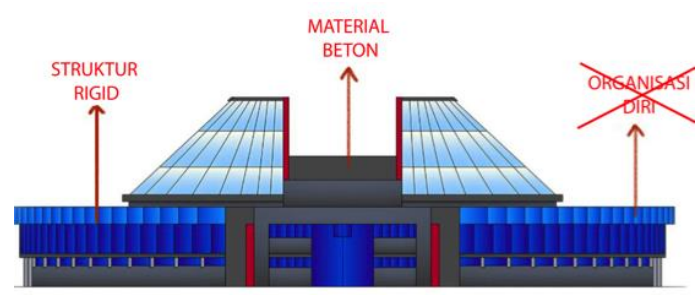

Gambar 2. Kondisi Taman Akuarium Air Tawar

Bangunan SeaWorld Ancol pun tidak memiliki kriteria organisasi diri. Pada gambar 4, dapat dilihat penggunaan material dan struktur sama seperti gambar 3. Salah satu buktinya adalah beton akan retak jika terjadi gempa, terlebih penggunaan struktur yang kaku.

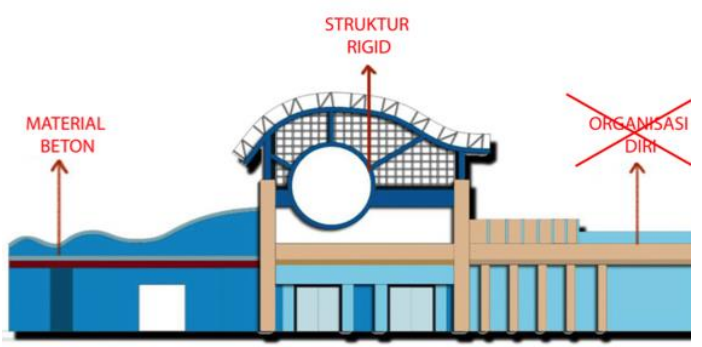

Gambar 3. Kondisi SeaWorld Ancol 


\section{Batasan (limitation)}

Kriteria batasan pada bangunan Taman Akuarium Air Tawar dapat dilihat pada gambar 5, dari aspek ukuran ruang akuarium utama. Satu ruang yang mayoritas bangunan oseanarium miliki yaitu akuarium utama. Akuarium utama juga menjadi daya tarik bangunan oseanarium yang paling tinggi (Judiono, Suharjanto, and Maringka 2017).

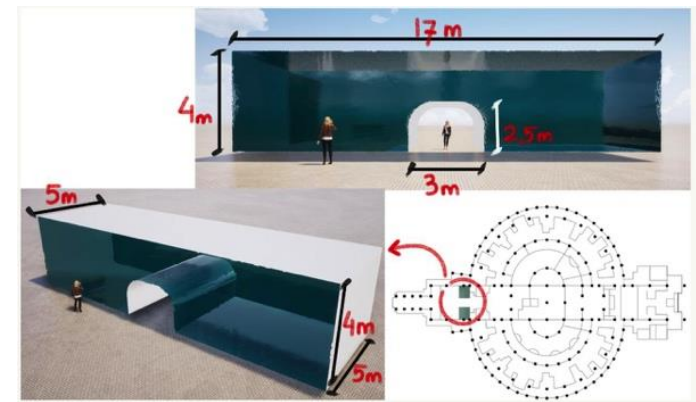

Gambar 4. Ukuran akuarium utama Taman Akuarium Air Tawar

Pada bangunan SeaWorld Ancol, kriteria batasan dapat dilihat pada gambar 6, dengan akuarium utamanya yang cukup menarik. SeaWorld Ancol memiliki akuarium utama yang merupakan salah satu akuarium laut terbesar di Asia Tenggara. Akuarium ini dilengkapi dengan lorong antasena sepanjang 80 meter.

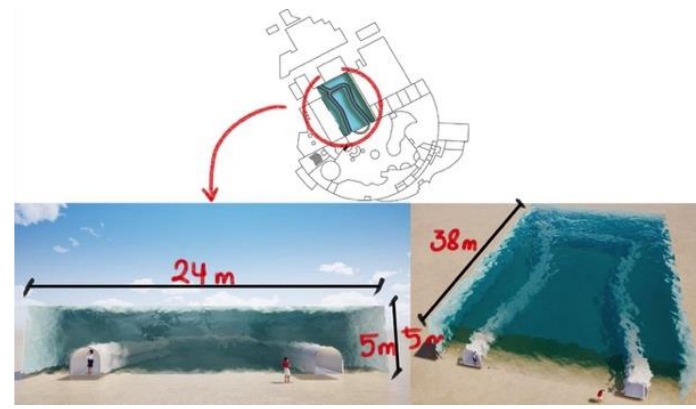

Gambar 5. Ukuran akuarium utama SeaWord Ancol

Keteraturan (order)

Kriteria keteraturan ditemukan pada penggunaan pola organisasi terpusat bangunan Taman Akuarium Air Tawar yang dapat dilihat pada gambar 7. Pola ini menciptakan ruang sentral yang dominan dan dikelilingi oleh sejumlah ruang-ruang pelengkap. Dengan komposisi pola struktur yang stabil dan terkonsentrasi bentuk bangunan terlihat simetris. Karena bentuk dari organisasi terpusat pada hakikatnya tidak memiliki satu arah, maka pencapaian dan sirkulasi pengunjung harus diperjelas pada bangunan.

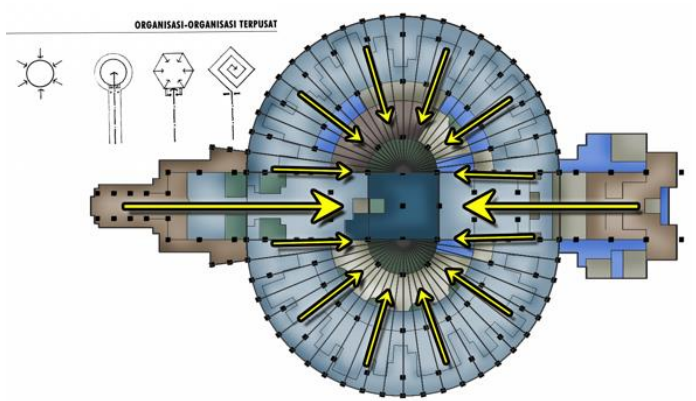

Gambar 6. Pola struktur terpusat pada Taman Akuarium Air Tawar

Pada bangunan SeaWorld Ancol tidak dapat ditemukan kriteria keteraturan. Dilihat pada gambar 8, dari aspek struktur, bentuk arsitektural maupun zonasi ruang bangunan ini tidak memenuhi kriteria keteraturan. Struktur yang tak berpola berdampak pada kesan bangunan yang tidak teratur. Terlihat jelas pada sirkulasi di dalam bangunan yang tidak terarah.

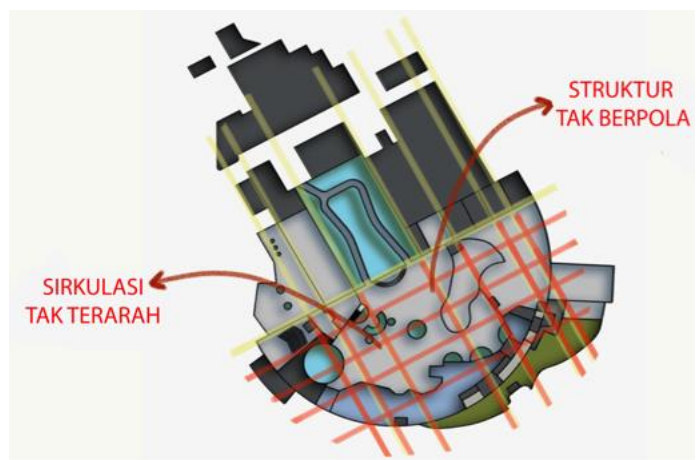

Gambar 7. Disharmoni pada SeaWord Ancol

Penyebaran (propagation)

Kriteria penyebaran pada bangunan dapat ditemukan sesuai dengan fungsi ruang. Kelompok ruang berdasarkan fungsi bukan sengaja didesain pada bangunan Taman Akuarium Air Tawar, melainkan didapati peneliti dari observasi fungsi tiap ruang pada bangunan. Pengelompokan ruang berdasarkan fungsi dapat dilihat pada gambar 9 di bawah ini. 


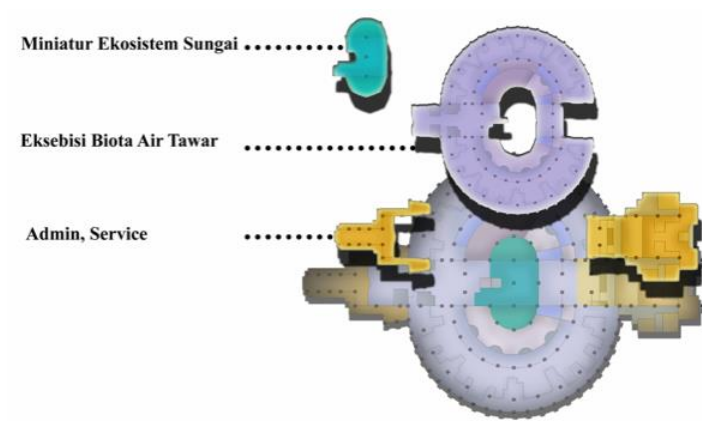

Gambar 9. Kelompok fungsi ruang pada Taman Akuarium Air Tawar

Bangunan SeaWorld Ancol merancang ruang eksebisi menjadi satu ruang utama dengan pelengkapnya. Setiap akuarium biota ditempatkan tanpa menggunakan zona pengelompokan tertentu. Kriteria penyebaran ditemukan secara keseluruhan bangunan berdasarkan fungsi yang dapat dilihat pada gambar 10 .

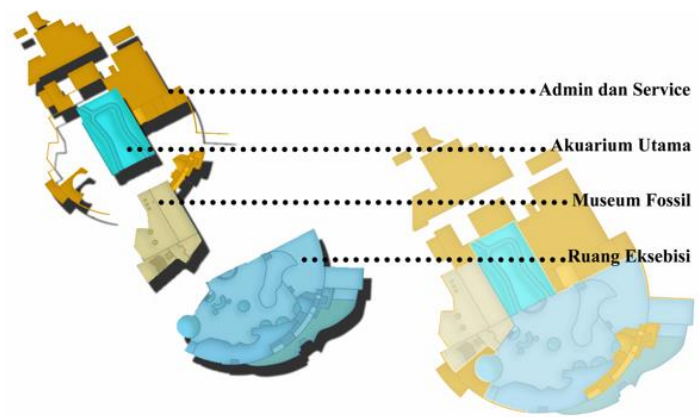

Gambar 8. Kelompok fungsi ruang pada SeaWord Ancol

Pertumbuhan (growth)

Bangunan Taman Akuarium Air Tawar sejak tahun pertama dibangunnya, denah dan bentuk arsitektural pada bangunan tidak ada yang diubah. Hal ini membuktikan secara jelas bahwa bangunan ini tidak memiliki kriteria pertumbuhan. Dari observasi peneliti mengenai bentuk denah, bangunan dan tapaknya pun terlihat tidak dapat dikembangkan seperti pada gambar 11. Peruntukkan disekitar bangunan sudah bersifat tetap dan menjangkau tapak bangunan lain, sehingga bangunan tidak dapat dikembangkan lagi berdasarkan tapak.

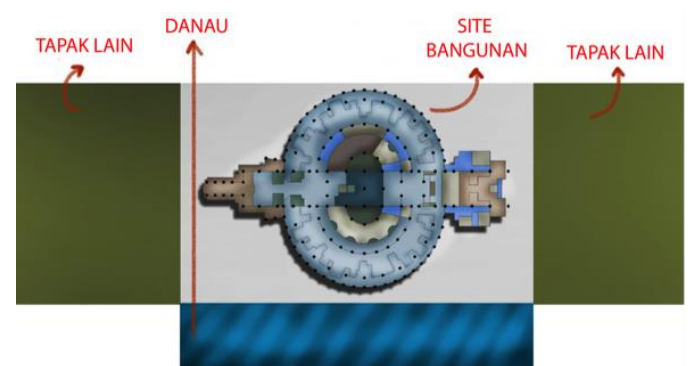

Gambar 11. Kondisi tapak Taman Akuarium Air Tawar

Pada bangunan SeaWorld Ancol pun tidak didapati adanya perkembangan bangunan sejak didirikan. Dengan keberadaan bangunan di kawasan rekreasi seperti bangunan Taman Akuarium Air Tawar, kedua bangunan ini memiliki satu tapak yang tetap terlihat pada gambar 12. Jika dibutuhkan perkembangan dimungkinkan secara vertikal. Namun pada kedua bangunan ini hal tersebut akan merubah integritas bangunan dan memungkinkan perubahan sistem pengoperasian pada akuarium.

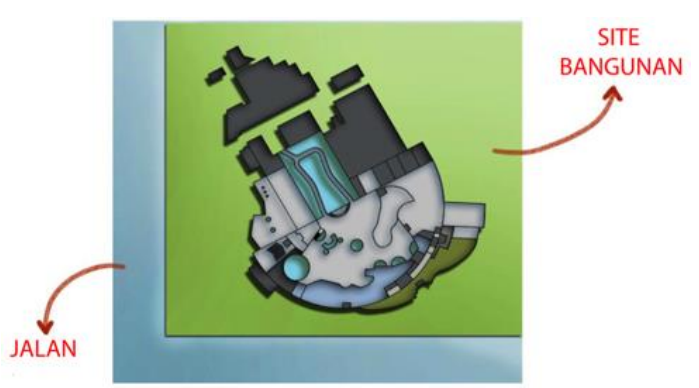

Gambar 9. Kondisi tapak SeaWorld Ancol

\section{Energi (energy)}

Pada bangunan Taman Akuarium Air Tawar kriteria energi dapat ditemukan dari penggunaaan material kaca pada atap sentral bangunan, terlihat pada gambar 13. Pada ruang sentral beratap kaca, tidak ditemukan penggunaan lampu pada siang hari karna cahaya masuk dari atap. Cahaya dari ruang sentral pun dapat memasuki ruang eksebisi di sampingnya dari pintu kaca dan mampu mengurangi penggunaan lampu pada ruang eksebisi. Penggunaan material pada atap ini membuktikan bahwa penggunaan material fasad memiliki peran penting dalam pengendalian limbah dan energi pada bangunan (López et al. 2017). 


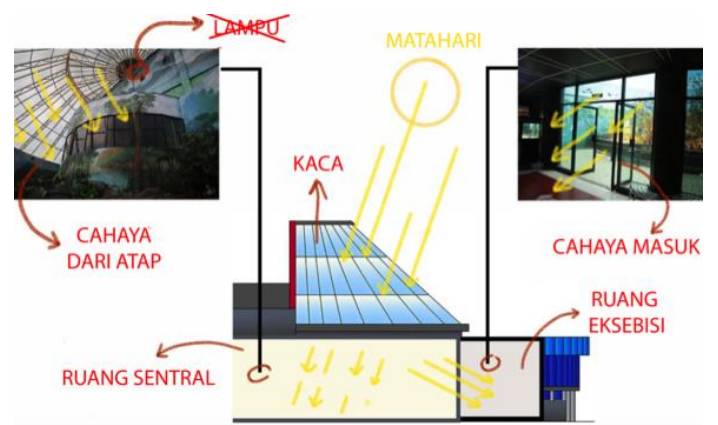

Gambar 13. Pencahayaan alami pada Taman Akuarium Air Tawar

Pada bangunan SeaWorld Ancol terlihat tidak mampu memberikan energi terbarukan dari segi pencahayaan alami. Terlihat pada gambar 14, ruang eksebisi pada bangunan yang sangat gelap. Gelapnya ruang di dalam bangunan mampu menyembunyikan instalasi listrik yang berada di langit-langit ruang eksebisi.

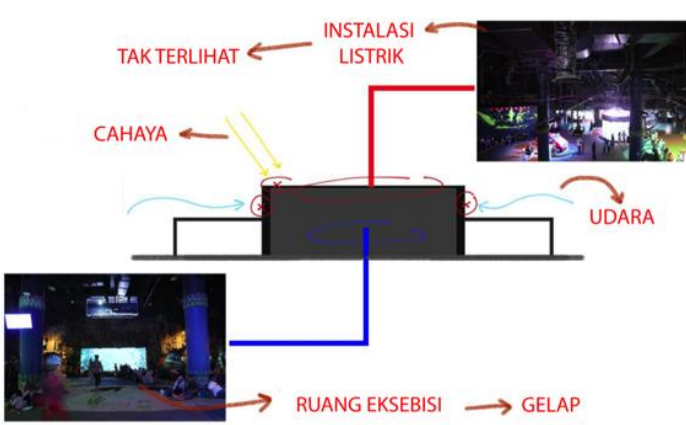

Gambar 10. Pencahayaan pada SeaWorld Ancol

\section{Reaksi (reaction)}

Reaksi pada bangunan Taman Akuarium Air Tawar dapat dilihat pada gambar 15. Pada denah awal ruang perpustakaan ditambahkan ruang UKS berdasarkan kebutuhan pasca huni. Ruang UKS didesain dengan satu brankar dan dibatasi oleh partisi-partisi rak buku perpustakaan.

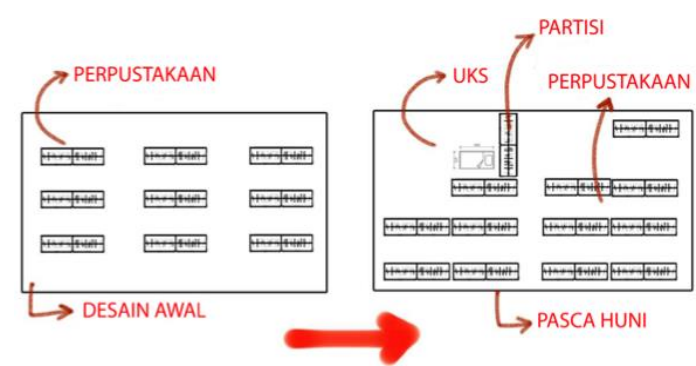

Gambar 11. Perubahan fungsi ruang pada Taman Akuarium Air Tawar
Pada bangunan SeaWorld Ancol, reaksi juga dapat dilihat dari elemen interiornya. Perubahan ini dapat dirasakan peneliti sebagai pengunjung di 8 tahun yang lalu. Reaksi pada elemen interior bangunan SeaWorld Ancol dapat dilihat pada gambar 16. Pada tahun 2011, seluruh ruangan hanya beralaskan lantai. Pada tahun 2019, beberapa area pertunjukan dengan kebutuhan tempat duduk dialaskan dengan karpet.

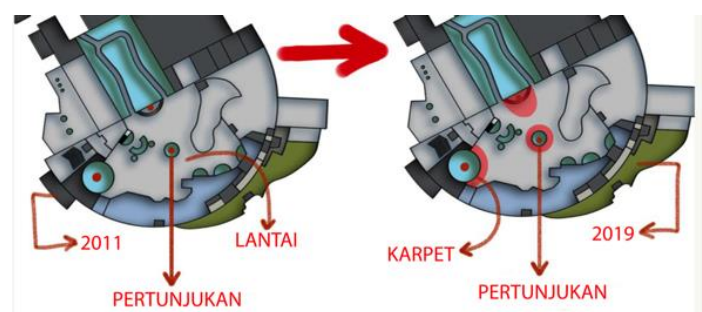

Gambar 12. Area penambahan karpet pada SeaWorld Ancol

Pihak pengurus SeaWorld menambahkan penggunaan karpet sebagai pada lantai beberapa area ruang eksebisi. Penggunaan karpet ini dilakukan karena aktifitas pengunjung yang harus duduk disaat beberapa pertunjukan berlangsung. Penggunaan karpet dilakukan di sekitar area akuarium pertunjukan. Hal ini tidak dilakukan di semua area dikarenakan adanya beberapa area basah pada ruang eksebisi.

\section{Evolusi (evolution)}

Evolusi atau perubahan pada bentuk atau fasad pada bangunan Taman Akuarium Air Tawar tidak dapat ditemukan. Dapat dilihat pada gambar 17, sejak tahun dibangunnya yaitu tahun 1994 hingga sekarang tidak dilakukan perubahan pada tampak dan bentuk bangunan ini.

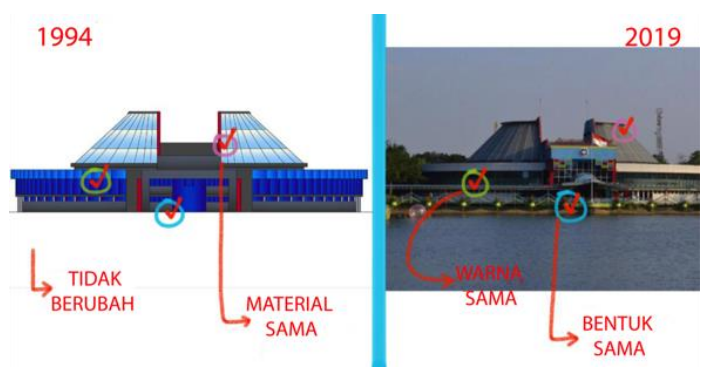

Gambar 13. Evolusi bangunan Taman Akuarium Air Tawar

Evolusi pada bangunan SeaWorld tidak ditemukan dari rentang waktu sejak bangunan terbangun hingga sekarang. Dilihat pada gambar 
18, tidak ada perubahan yang dilakukan pada fasad dan bentuk bangunan dari tahun 1994 hingga 2019.

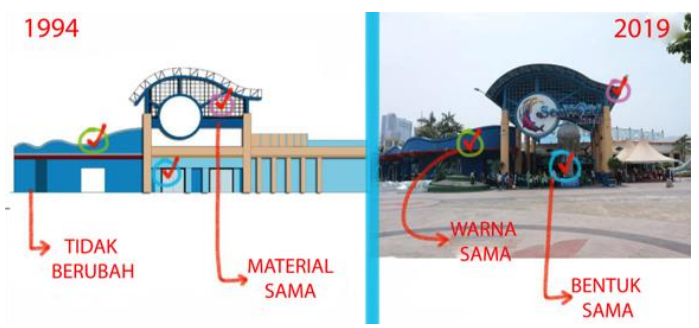

Gambar 14. Evolusi bangunan SeaWorld Ancol

\section{Mimesis (peniruan)}

Taman akuarium air tawar memiliki kriteria mimesis pada aspek bentuk bangunan. Dilihat pada gambar 19, bentuk bangunan menirukan bentuk tempurung kura-kura. Hal ini pun ternyata memiliki hubungan dengan tema eksebisi di dalamnya yaitu kura-kura sebagai biota air tawar.

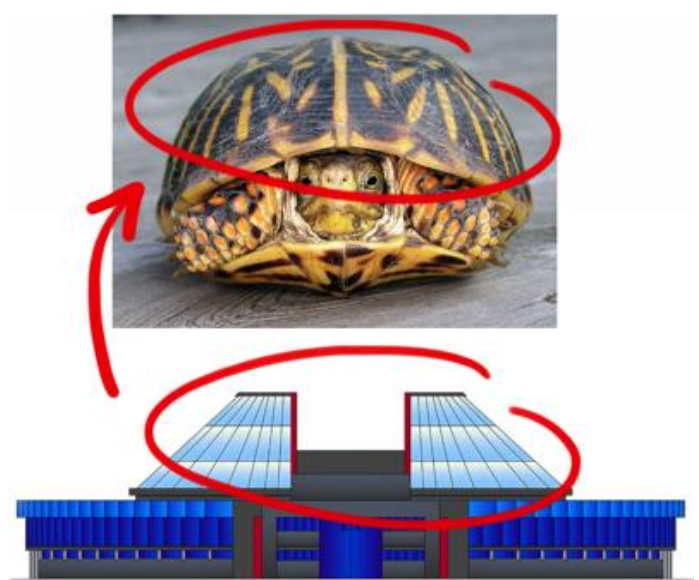

Gambar 15. Bentuk bangunan Taman Akuarium Air Tawar

Bangunan Taman Akuarium Air Tawar juga memiliki kriteria mimesis pada bentuk denahnya. Berbeda dengan bentuk bangunannya, bentuk denah bangunan ini menirukan sebuah ikan yang cukup populer pada masa dibangunnya bangunan ini yaitu ikan terbang. Terlihat dari gambar $20 \mathrm{di}$ bawah ini, dapat dilihat bagaimana bentuk denah bangunan ini menirukan bentuk dari ikan terbang.

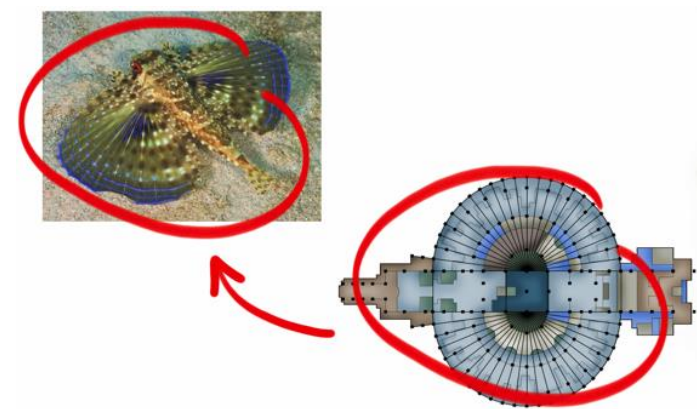

Gambar 20. Bentuk siteplan Taman Akuarium Air Tawar

Bangunan SeaWorld Ancol memiliki kriteria mimesis pada bentuk denah dari bangunan ini. Dilihat dari gambar 21, dengan tema eksebisinya yaitu biota laut bentuk denah bangunan ini menirukan bentuk setengah lingkaran ubur-ubur. Peniruan bentuk ini memang terkesan abstrak, namun diperjelas kembali pada beberapa ornamen bangunan yang menjadikan ubur-ubur sebagai tema dari bentuk bangunan ini.

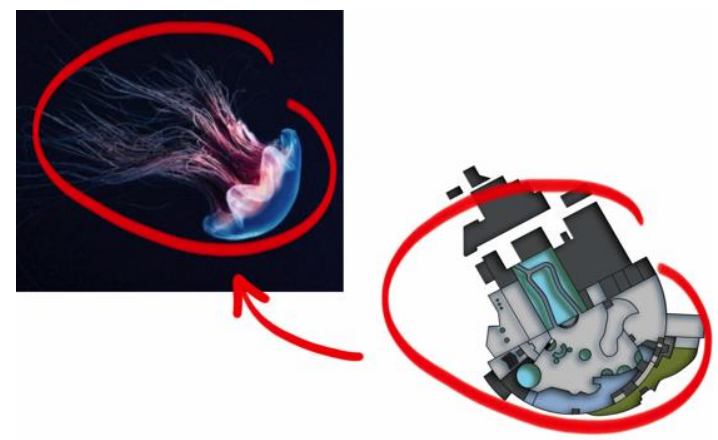

Gambar 16. Bentuk siteplan SeaWorld Ancol

Adapun kriteria mimesis pada bangunan SeaWorld yaitu pada interior bangunan. dapat dilihat pada gambar 22, interior bangunan menirukan kegelapan dari bawah laut dan menghadirkan ornamen-ornamen bawah laut. Penemuan mimesis pada interior bangunan ini membuktikan bahwa kesinambungan konsep desain oseanarium sebagai bangunan yang berhubungan dekat dengan biota laut akan jauh lebih menarik jika merefleksikannya pada interior bangunannya (Mazzoleni 2013). 


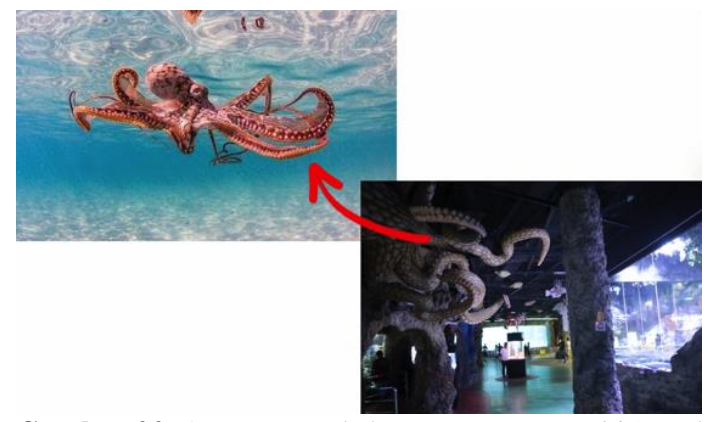

Gambar 22. Ornamen pada bangunan SeaWorld Ancol

Pada kriteria mimesis yang ditemukan di interior bangunan SeaWorld Ancol memberikan nilai tambah bagi pengguna bangunan. Hal ini mampu memberikan kesan nyata bahwa penggunan berada di bawah laut dan berada bersama biota-biota di dalamnya. Peniruan pada aspek ini memberikan interaksi lebih kepada pengunjung.

\section{Kesimpulan}

Arsitektur biomimetik merupakan sebuah konsep perancangan yang mampu menciptakan sebuah karya arsitektur dengan desain yang memaksimalkan efisiensi energi dan kualitas ruang dan bangunan yang diadaptasi dari peniruan cara kerja atau kriteria biologis.

Pengembangan kelayakan konsep arsitektur biomimetik, diperlukan sebagai jawaban dari permasalahan penelitian yang mengenai bagaimana penerapan dari tiap kriteria biologis arsitektur biomimetik.

Setiap kriteria biologis memiliki cara dan elemen tertentu pada bangunan dalam pengaplikasiannya. Dari kriteria biologis yang pertama yaitu Keterbukaan, diaplikasikan dengan penggunaan elemen arsitektural yang mampu memberikan kesan luas yang dapat dilihat dan atau dirasa pengguna bangunan. Kriteria organisasi diri yang diaplikasikan dengan penggunaan bentuk bangunan, material bahkan struktur yang mampu menyesuaikan diri terhadap kondisi alam. Kriteria batasan, yang menerapkan ukuran berdasarkan kapasitas pada ruang. Kriteria keteraturan dengan mengatur struktur dan sirkulasi bangunan berdasarkan sebuah pola. Kriteria penyebaran yang mengelompokan ruang berdasarkan fungsi. Kriteria pertumbuhan dengan merancang bangunan bertahap demi menyesuaikan kapasitas mendatang. Kriteria energi dengan menerapkan sistem energi terbarukan/alami. Kriteria Reaksi yang merancang bangunan dengan perkiraan kebutuhan paska huni sebuah bangunan. Kriteria evolusi yang merancang konsep bangunan dengan perkiraan perkembangan zaman agar bangunan tetap menarik dan tak lekang oleh waktu. Adapun kriteria mimesis sebagai kriteria pamungkas yang diaplikasikan dengan menirukan bentuk atau cara kerja alam pada elemen arsitektural, seperti bentuk bangunan.

Dari tiap kriteria yang diteliti dapat menjawab permasalahan mengenai pengaruh dari tiap kriteria terhadap bangunan. Mulai dari kriteria keterbukaan yang dapat memberi kesan luas dan meningkatkan aksesibilitas antar ruang pada oseanarium. Kriteria organisasi diri, memberikan kemampuan bangunan dalam bertahan dari segala kondisi alam sekitarnya dengan menyesuaikan diri. Kriteria batasan yang memaksimalkan kebutuhan suatu ukuran seperti ruang dalam memenuhi kapasitasnya. Kriteria keteraturan yang memberikan kesan terarah dan terkonsep pada segala aspek bangunan. Kriteria penyebaran yang membantu pengelompokan ruang terhadap zonasi dan konsep yang sesuai. Kriteria pertumbuhan yang memungkinkan sebuah bangunan terus memenuhi kebutuhan kapasitasnya secara berkelanjutan. Kriteria energi yang memanfaatkan energi terbarukan dan mencegah penggunaan energi habis terpakai. Kriteria reaksi yang dapat mengelola kebutuhan bangunan dalam menjawab kebutuhan paska huni. Adapun kriteria evolusi yang juga mengelola kebutuhan bangunan namun dalam menjawab kebutuhan perkembangan zaman. Dengan menerapkan semua kriteria yang telah disebutkan, mampu menciptakan sebuah bangunan oseanarium yang berkelanjutan, bernilai ekologis tinggi, nyaman, menarik dan tidak lekang oleh waktu.

Dari semua pengaruh positif yang terlihat pada bangunan oseanarium, dapat dibuktikan bahwa konsep arsitektur biomimetik layak dikembangkan dan digiatkan penggunaanya untuk meminimalisir dampak negatif dari pembangunan. Dengan menerapkan ilmu yang telah alam ajarkan dari tiap bentuk dan cara kerja makhluk hidup di sekitar manusia, pembangunan akan menjadi seimbang dengan ekosistem di sekitarnya. Sehingga, perkembangan manusia akan terus berjalan tanpa memperburuk keadaan alam di sekitarnya. 


\section{Referensi}

Aizenberg, Joanna, and Peter Fratzl. 2009. 'Biological and Biomimetic Materials'. Advanced Materials 21 (4): 387-88. https://doi.org/10.1002/adma.200803699.

Al-Obaidi, Karam M., Muhammad Azzam Ismail, Hazreena Hussein, and Abdul Malik Abdul Rahman. 2017. 'Biomimetic Building Skins: An Adaptive Approach'. Renewable and Sustainable Energy Reviews 79 (November): 1472-91. https://doi.org/10.1016/j.rser.2017.05.028.

Amna, Lailatul. 2017. 'Penerapan Arsitektur Ekologi Dalam Perancangan Pusat Penelitian Agrikultur Di Kabupaten Sragen'. $\begin{array}{lll}\text { ARSITEKTURA } & 15 & \text { (2): } 489 .\end{array}$ https://doi.org/10.20961/arst.v15i2.15236.

Badarnah, Lidia, and Usama Kadri. 2015. 'A Methodology for the Generation of Biomimetic Design Concepts'. Architectural Science Review 58 (2): 120-33. https://doi.org/10.1080/00038628.2014.9224 58.

Dewi Wulansari, Maria Ariadne, and Dimas Wihardyanto. 2017. 'Metodologi Penilaian Kualitas Hunian Paska Bencana Sebagai Evaluasi Strategi Rekonstruksi: Analisis Faktual Dan Perseptual'. LANGKAU BETANG: JURNAL ARSITEKTUR 4 (2): 89. https://doi.org/10.26418/lantang.v4i2.23272.

Eman, Arviro, and Octavianus H. A. Rogi. 2013. 'Implementasi Konsep Arsitektur Biomimetik Pada Desain Gelanggang Olahraga Di Minahasa Selatan'. Jurnal Arsitektur DASENG UNSRAT 2 (1): 31-41. https://ejournal.unsrat.ac.id/index.php/daseng /article/view/3457/pdf.

Gruber, Petra. 2011. Biomimetics in Architecture: Architecture of Life and Buildings. New York City: Springer.

Hartono, Garbielle D. A., Pingkan P. Egam, and Amanda S. Sembel. 2018. 'Pusat Hewan Peliharaan Di Kota Manado. Arsitektur Biomimetik'. Jurnal Arsitektur DASENG UNSRAT 7 (1). https://ejournal.unsrat.ac.id/index.php/daseng /article/view/20448.

Hijriati, Emma, and Rina Mardiana. 2014. 'Pengaruh Ekowisata Berbasis Masyarakat Terhadap Perubahan Kondisi Ekologi, Sosial, Dan Ekonomi Di Kampung Batusuhunan,
Sukabumi'. Sodality: Jurnal Sosiologi Pedesaan 2 (3): 146-59.

Judiono, Diandra Aprilia, Didiek Suharjanto, and Breeze Maringka. 2017. 'Public Aquarium Di Kota Malang, Tema: Arsitektur Bioclimatic'. Pengilon 1 (1): 45-56.

Kelly, Lisa-Anne DeGregoria, Jerry F. Luebke, Susan Clayton, Carol D. Saunders, Jennifer Matiasek, and Alejandro Grajal. 2014. 'Climate Change Attitudes of Zoo and Aquarium Visitors: Implications for Climate Literacy Education'. Journal of Geoscience Education $\quad 62 \quad$ (3): $\quad 502-10$. https://doi.org/10.5408/13-078.1.

Knippers, Jan, Klaus G. Nickel, and Thomas Speck, eds. 2016. Biomimetic Research for Architecture and Building Construction. Vol. 8. Biologically-Inspired Systems. Cham: Springer International Publishing. https://doi.org/10.1007/978-3-319-46374-2.

Larasati, Nisriana Nadya, Agus Heru Purnomo, and Hardiyati. 2018. 'Konservasi Biota Laut Sebagai Dasar Perancangan Oseanarium Di Pangandaran'. Senthong: Jurnal Ilmiah Mahasiswa Arsitektur 1 (1): 73-83. https://jurnal.ft.uns.ac.id/index.php/senthong/ article/view/664/381.

López, Marlén, Ramón Rubio, Santiago Martín, and Ben Croxford. 2017. 'How Plants Inspire Façades. From Plants to Architecture: Biomimetic Principles for the Development of Adaptive Architectural Envelopes'. Renewable and Sustainable Energy Reviews $67 \quad$ (January): 692-703. https://doi.org/10.1016/j.rser.2016.09.018.

Mazzoleni, Ilaria. 2013. Architecture Follows Nature-Biomimetic Principles for Innovative Design. Boca Raton, Florida, Amerika Serikat: CRC Press.

Pawlyn, Michael. 2019. Biomimicry in Architecture. 2nd Editio. London: RIBA Publishing. https://doi.org/10.4324/9780429346774.

Purwantiasning, Ari Widyati. 2015. 'Kajian Revitalisasi Pada Bantaran Sungai Sebagai Upaya Pelestarian Bangunan Tua Bersejarah, Studi Kasus: Kawasan Malaka, Malaysia’. In Simposium Nasional Teknologi Terapan (SNTT) 3. Surakarta: Universitas Muhammadiyah Surakarta. https://publikasiilmiah.ums.ac.id/bitstream/ha ndle/11617/6232/1. 
SNTT_2015_submission_1.pdf?sequence $=1$ \&isAllowed=y.

Schouten, Frendy P. Y., Sangkertadi, and Frits O. P. Siregar. 2015. 'Biodome Di Manado (Arsitektur Biomimetika)'. Jurnal Arsitektur DASENG UNSRAT 4 (2): 109-18. https://ejournal.unsrat.ac.id/index.php/daseng /article/view/8890/pdf.

Sunarmi. 2014. 'Melestarikan Keanekaragaman Hayati Melalui Pembelajaran Di Luar Kelas Dan Tugas Yang Menantang'. Jurnal Pendidikan Biologi 6 (1): 38-49. http://journal.um.ac.id/index.php/jpb/article/v iew/7824.

Suryadi, Machfudz Ardi. 2018. 'Perancangan Pusat Kuliner Berbahan Unggas Dengan Pendekatan Biomimicry Architecture Di Kabupaten Malang'. Universitas Islam Negeri Maulana Malik Ibrahim. http://etheses.uinmalang.ac.id/12366/. 